\title{
Borderline-tuberculoid leprosy in reaction presenting as photodermatitis: a case report
}

\author{
E FEKETE, P A SAROJINI \& B MOCK \\ All Africa Leprosy Rehabilitation and Training Centre, ALERT, \\ PO Box 165, Addis Ababa, Ethiopia
}

Received for publication 24 November 1981

Summary A 30-year-old female patient with BT leprosy in reaction presented as a case of photodermatitis. The diagnosis was confirmed by the skin biopsy and demonstration of AFB in the biopsy section.

\section{Introduction}

Leprosy in reaction can mimic many other diseases, especially the collagen disorders. But the presentation as photodermatitis is not common and since no previous reference of such a case could be found, ${ }^{1-4}$ it was decided to report this case.

\section{Case report}

BT card No STO 7276 - a 30-year-old female patient, was referred from Yekatit 12th Hospital to ALERT Hostpital on 14.5.1981 for a photodermatitis and rheumatic pains of 1 year's duration. A presumptive diagnosis of dermatomyositis was made at Yekatit 12th Hospital and she was put on steroids, which gave a temporary improvement. The patient gave no history of drugtaking prior to the onset and she had no skin lesion 1 year previously.

O/E: Patient had a diffuse erythema and swelling of the face, V-area of her neck, exposed parts of forearms, hands and feet. The erythema and oedema were strictly localized to the exposed areas. The area of the forehead covered by her turban was completely free. A probable diagnosis of systemic lupus erythematosus (SLE) was made because of the persistent photodermatitis of 1 year's duration and rheumatic pains. There was no Raynaud's phenomenon, 


\section{$116 \quad$ E Fekete et al.}

no enlargement of the liver and spleen, and no abnormalities were detected in the lungs or heart. There were no skin lesions elsewhere and no enlargement of peripheral nerves. Records from Yekatit 12th Hospital showed that she had a puffy face and oedema of the hands and feet of 1 year's duration. $\mathrm{Hb}, 11.5 \mathrm{~g} \%$; $\mathrm{WBC}, 6558 / \mathrm{cmm}$; ESR, $44 \mathrm{~mm} / \mathrm{h}$; blood urea, $4 \mathrm{mg} \%$; urine, nothing abnormal; urine culture, sterile; fasting blood sugar, $90 \mathrm{mg} \%$; stool, no ova or parasites; LE cells, neg; skin biopsy, granumola; no AFB.

\section{Investigation at ALERT Hospital}

Skin smears for AFB from 6 sites: No AFB. WBC, $9750 \mathrm{cmm}$; Hb, $14.7 \mathrm{gm} \%$; ESR, $25 \mathrm{~mm} / \mathrm{h}$; differential leucocyte count, P:78, L:18, M:11, Eo:1; Mantoux test, neg; Skin biopsy, epidermis normal. In the upper and mid-dermis there was loosely constructed epithelioid granuloma with several small giant cells and a good number of lymphocytes. There was one oedematous nerve with onion-peel perineurium containing infiltrate. Fite stain showed few intraneural AFB. Conclusion: BT leprosy in reaction.

The patient was prescribed steroids and DDS. She has improved well. Erythema and oedema have become much less. She was discharged on 18.6.1981, with a sliding dose of steroids and DDS $100 \mathrm{mg}$ daily.

\section{Discussion}

This case is very unusual. A BT female patient presented as a case of photodermatitis and therefore went to a general hospital. Because of her photodermatitis and rheumatic pains she was investigated on suspicion of a collagen disease. The only clue suggestive of leprosy in this case was the skin biopsy which showed granuloma. Sarcoidosis was excluded because few AFB could be demonstrated in the biopsy. Here the final diagnosis of leprosy was made by the histology section.

This case should heighten our awareness that, especially in endemic areas, leprosy in reaction can have unusual presentations. All necessary investigations including biopsy and special stain for AFB should be done in such cases. We should always be aware of this fact.

\section{Acknowledgement}

We wish to express our thanks to the Directors of ALERT and AHRI for permitting us to use the facilities available in these institutions. We are also thankful to Dr J Warndorff for reading the histopathology section. 


\section{References}

1 Bryceson A, Pfaltzgraff RE. Leprosy. 2nd ed. Edinburgh: Churchill Livingstone, 1979.

2 Cochrane RG, Davey JE, McRobert G. Leprosy in theory and practice. 2nd ed. Bristol: John Wright and Sons Ltd. 1964.

3 Dharmendra. Leprosy. vol I. India: The Kothari Medical Publishing House. 1978.

4 Jopling WH. Handbook of Leprosy. 2nd ed. London: William Heinemann Books Ltd. 1978. 